\title{
Rehydration Properties of Whey Protein Isolate Powders Containing Nanoparticulated Proteins
}

\author{
Jacob R. Guralnick ${ }^{1}$, Ram R. Panthi ${ }^{1}$, Valeria L. Cenini ${ }^{2}$, Vinay S. N. Mishra ${ }^{3}{ }^{\circledR}$, Barry M. G. O'Hagan ${ }^{2}$, \\ Shane V. Crowley ${ }^{1}$ and James A. O'Mahony ${ }^{1, *}$ \\ 1 School of Food and Nutritional Sciences, University College Cork, T12K8AF Cork City, Ireland; \\ 116224471@umail.ucc.ie (J.R.G.); ram.panthi@ucc.ie (R.R.P.); shane.crowley@ucc.ie (S.V.C.) \\ 2 Bioimaging Core Facility Unit, Biomedical Science Research Institute, Ulster University, \\ Coleraine BT52 1SA, UK; v.cenini@ulster.ac.uk (V.L.C.); bmg.ohagan@ulster.ac.uk (B.M.G.O.) \\ 3 National Food Imaging Centre (NFIC), Teagasc Food Research Centre, \\ Department of Food Chemistry and Technology, Moorepark, P61C996 Fermoy, Ireland; \\ Vinay.Mishra@teagasc.ie \\ * Correspondence: sa.omahony@ucc.ie; Tel.: +353-21-490-3625
}

check for updates

Citation: Guralnick, J.R.; Panthi, R.R.; Cenini, V.L.; Mishra, V.S.N.; O'Hagan, B.M.G.; Crowley, S.V.; O'Mahony, J.A. Rehydration Properties of Whey Protein Isolate Powders Containing Nanoparticulated Proteins. Dairy 2021, 2, 602-616. https://doi.org/10.3390/dairy2040047

Academic Editor: Manuel Castillo Zambudio

Received: 21 May 2021

Accepted: 26 September 2021

Published: 27 October 2021

Publisher's Note: MDPI stays neutral with regard to jurisdictional claims in published maps and institutional affiliations.

Copyright: (c) 2021 by the authors. Licensee MDPI, Basel, Switzerland. This article is an open access article distributed under the terms and conditions of the Creative Commons Attribution (CC BY) license (https:// creativecommons.org/licenses/by/ $4.0 /)$.

\begin{abstract}
The rehydration properties of original whey protein isolate $\left(\mathrm{WPI}_{\mathrm{C}}\right)$ powder and spray-dried WPI prepared from either unheated $\left(\mathrm{WPI}_{\mathrm{UH}}\right)$ or nanoparticulated WPI solutions were investigated. Nanoparticulation of whey proteins was achieved by subjecting reconstituted $\mathrm{WPI}_{\mathrm{C}}$ solutions $(10 \%$ protein, $w / w, \mathrm{pH} 7.0)$ to heat treatment at $90{ }^{\circ} \mathrm{C}$ for $30 \mathrm{~s}$ with no added calcium $\left(\mathrm{WPI}_{\mathrm{H}}\right)$ or with $2.5 \mathrm{mM}$ added calcium $\left(\mathrm{WPI}_{\mathrm{HCa}}\right)$. Powder surface nanostructure and elemental composition were investigated using atomic force microscopy and X-ray photoelectron spectroscopy, followed by dynamic visualisation of wetting and dissolution characteristics using environmental scanning electron microscopy. The surface of powder particles for both $\mathrm{WPI}_{\mathrm{UH}}$ and $\mathrm{WPI}_{\mathrm{C}}$ samples generally appeared smooth, while $\mathrm{WPI}_{\mathrm{H}}$ and $\mathrm{WPI}_{\mathrm{HCa}}$ displayed micro-wrinkles with more significant deposition of nitrogen and calcium elements. $\mathrm{WPI}_{\mathrm{H}}$ and $\mathrm{WPI}_{\mathrm{HCa}}$ exhibited lower wettability and solubility performance than $\mathrm{WPI}_{\mathrm{UH}}$ and $\mathrm{WPI}_{\mathrm{C}}$ during microscopic observation. This study demonstrated that heat-induced aggregation of whey proteins, in the presence or absence of added calcium, before drying increases aggregate size, alters the powder surface properties, consequently impairing their wetting characteristics. This study also developed a fundamental understanding of WPI powder obtained from nanoparticulated whey proteins, which could be applied for the development of functional whey-based ingredients in food formulations, such as nanospacers to modulate protein-protein interactions in dairy concentrates.
\end{abstract}

Keywords: whey protein; milk powder; rehydration; aggregation; nanoparticulation

\section{Introduction}

Whey protein ingredients, such as whey protein isolate (WPI), have a wide range of applications in food formulations due to their diverse techno-functional and nutritional properties [1]. The functionality of whey proteins can be tailored for applications such as fat mimetics and encapsulation, through processes such as heat treatment, high-pressure processing or enzymatic treatment. Applying such treatments separately or in combination to WPI solutions prior to drying leads to the development of novel WPI powders with unique functional properties, customized for specific applications [2,3]. This has aided the response to the continual demand by the food industry for ingredients with tailored functionalities [4] driven by cleaner labels, diversification into new markets and regulatory considerations [5]. However, understanding the rehydration properties (i.e., wetting, swelling, sinking, dispersion and dissolution characteristics) of novel WPI powders is required to underpin their potential applications in food formulation. It is well-established 
that wetting is the rate-limiting step during rehydration for WPI powders and poor wetting is most often manifested as powder clump formation on the surface of water [6].

The poor wetting properties of WPI powders arise from hydrophobic protein chains leading to the formation of large aggregates and coating of powder particle surfaces with lipids $[7,8]$. In addition, processing and storage conditions influence the microstructural properties of WPI powders. For example, WPI samples prepared at $\mathrm{pH} 6.5$ exhibited a loss of soluble protein from 90 to $23 \%$ during $24 \mathrm{~h}$ of dry heating at $100{ }^{\circ} \mathrm{C}$, as a result of denaturation and aggregation of whey proteins, leading to increased aggregate size from 56 to $220 \mathrm{~nm}$ through the formation of complexes [9]. Heat-induced alteration of WPI increases the surface hydrophobicity, with consequent impairment in rehydration characteristics of these powders [10]. Furthermore, denaturation and aggregation of whey proteins is favoured when the electrostatic repulsion between molecules is decreased through solvent conditions (e.g., $\mathrm{pH}$, ionic strength, presence of cations), resulting in changes in protein molecule/aggregate size, microstructure, reactivity and colloidal stability $[9,11]$. Thus, whey protein aggregate size and related surface reactivity can be controlled by heating temperature $\left(72\right.$ to $\left.85^{\circ} \mathrm{C}\right)$ and level of divalent cations $\left(2.2 \mathrm{mM} / \mathrm{L} \mathrm{Ca}^{2+}\right)$ in the solution leading to the formation of protein complexes via salt bridges [12]. More specifically, a previous study has shown that aggregated whey protein particles in the micrometre $(>1 \mu \mathrm{m}$; i.e., microparticulation) or nanometre $(<1 \mu \mathrm{m}$; i.e., nanoparticulation) scales can be formed depending on the processing parameters $\left(72-85^{\circ} \mathrm{C}, 0-2.2 \mathrm{mM}\right.$ calcium), whey protein concentration and $\mathrm{pH}$ (in the range 2.5-6.5) [9,12]. Such alterations to the surface structures and aggregate size may influence water penetration, and thereby swelling, of such powders in water, impacting their rehydration performance. The subject of previous studies focusing on the improvement of rehydration properties include microfluidization [13], microparticulation [14], high-pressure treatment [15] and conjugation [16]. The previous study from our group showed the modulation of whey protein aggregate size through heat treatment and solvent conditions (e.g., Ca concentration) [17] and application of such aggregates in an infant milk formula system showed potential improvement of processing performance of the solution [18].

The influence of the process on powder properties and, consequently on rehydration characteristics, can be established by measuring the powder surface composition and imaging their micro-and nano-structures. The application of microscopic techniques facilitates understanding of the changes of the physical, structural and functional (e.g., swelling, wetting and/or dispersion) properties of powders during their rehydration [19]. Particularly, the utilisation of Environmental Scanning Electron Microscopy (ESEM) facilitates the analysis in situ of the powder particle morphological and physical changes in real-time and at high resolution during hydration and reconstitution [20]. Moreover, topographical assessment of powders using atomic force microscopy (AFM) provides 2- or 3-dimensional insights on powder surface structures [10], while X-ray photoelectron spectroscopy (XPS) reveals elemental composition at the powder surface [7]. Recent developments in soundbased technology can calculate gas (i.e., air) release from powder particles by measuring the frequency of sound through powder dispersion, which is linked to water transport properties during rehydration [21,22]. While the functional properties and applications of microparticulated whey proteins are reasonably well studied, the functionality, or surface properties of powder particles, of nanoparticulated whey protein powders is largely unknown. The utilisation of advanced analytical techniques facilitates the understanding of powder properties and their rehydration characteristics, as influenced by novel processes such as nanoparticulation of whey proteins prior to drying.

The overall objective of this study was to investigate the rehydration properties (wetting, swelling, dispersion and dissolution) of WPI powders produced from nanoparticulated whey proteins through heat- and mineral-induced denaturation and aggregation $\left(90^{\circ} \mathrm{C}\right.$, with or without $2.5 \mathrm{mM}$ added calcium) and to compare them with an unheated WPI powder. This study will further the understanding of how nanoparticulation of whey proteins prior to spray-drying influences microstructure, powder surface structures, and 
the rehydration properties of resultant WPI powders. Such novel whey protein-based dairy ingredients can be applied in food formulations as thermally and colloidally stable alternatives to native whey protein, reducing subsequent protein-protein interactions.

\section{Materials and Methods}

\subsection{Materials}

Whey protein isolate $\left(\mathrm{WPI}_{\mathrm{C}} ; \mathrm{BiPro}^{\circledR}\right)$ powder was provided by Agropour (SaintHubert, Longueuil, QC, Canada). Calcium chloride (1 M), and all other chemicals and reagents, were obtained from Sigma-Aldrich (St. Louis, MO, USA).

\subsection{Powder Preparation}

The production of WPI powders prepared from nanoparticulated whey proteins was performed as described previously [23]. Briefly, $\mathrm{WPI}_{C}$ powder was rehydrated in ultrapure water at $10 \%(w / w)$ protein while stirring suspensions using an overhead stirrer at $150 \mathrm{rpm}$ for $2 \mathrm{~h}$ at $25^{\circ} \mathrm{C}$, after which dispersions were adjusted to $\mathrm{pH} 7.0$ using $1 \mathrm{~N} \mathrm{HCl} / \mathrm{NaOH}$, and rehydrated overnight at $4{ }^{\circ} \mathrm{C}$. Three WPI solutions were prepared under different thermal treatment conditions and calcium additions to target different extents of denaturation and aggregation of the whey proteins, informed by results of a preliminary study [23]. Samples generated were: an unheated WPI solution $\left(\mathrm{WPI}_{\mathrm{UH}}\right)$, WPI solution heated $\left(90^{\circ} \mathrm{C}\right.$ for $30 \mathrm{~S}$ ) without added calcium $\left(\mathrm{WPI}_{\mathrm{H}}\right)$ or heated with $2.5 \mathrm{mM}$ added calcium $\left(\mathrm{WPI}_{\mathrm{HCa}}\right)$. For $\mathrm{WPI}_{\mathrm{Hca}}, 1 \mathrm{M} \mathrm{CaCl}_{2}$ solution was added to ultrapure water to prepare a $2.5 \mathrm{mM}$ solution in which WPIc powder was solubilised. Thermal treatments were applied in a continuous flow manner $(1 \mathrm{~L} / \mathrm{min})$ using a high-temperature short-time Microthermics instrument (Microthermics, Raleigh, NC, USA) to batches of $60 \mathrm{~L}$ each. Solutions ( $10.6 \%$ total solids) were spray-dried using a single-stage Niro 25 dryer (GEA, Søborg, Denmark) with inlet and outlet temperatures of 180 and $80^{\circ} \mathrm{C}$ without pre-concentration to prevent any further aggregation; dryer inlet and outlet temperatures were chosen to target $4-6 \%$ moisture in final powders.

\subsection{Composition of Whey Protein Isolate Powders}

Protein content was determined by Kjeldahl method with nitrogen-to-protein conversion factor 6.38 [24] and moisture content using an oven-drying method at $103{ }^{\circ} \mathrm{C}$ [25].

\subsection{Surface Elemental Composition of Whey Protein Isolate Powders}

Surface elemental composition of WPI powders was determined using an X-ray photoelectron spectrophotometer (XPS) as described by McCarthy et al. [26]; briefly, a Kratos Axis 165 XPS (Kratos Analytical, Manchester, UK), with a monochromatic Al K $\alpha$ X-ray source $(1486.58 \mathrm{eV})$ at $150 \mathrm{~W}(15 \mathrm{kV}, 10 \mathrm{~mA})$, was utilised and the powder samples were attached to the sample holder prior to analysis using double-sided conductive tape.

\subsection{Surface Topography of Whey Protein Isolate Powders}

Topographical scans of WPI powders were acquired utilising AFM (Molecular force probe-3D, MFP-3D ${ }^{\mathrm{TM}}$, Oxford Instruments, Santa Barbara, CA, USA). Powder particles were sprayed using the sample dispersion unit of a Malvern morphology G3 instrument (Malvern Instruments Ltd., Worcestershire, UK) at 6 bar air pressure. Particles were adhered to a mica surface, which was fixed onto a glass slide with epoxy glue and samples were observed using light microscopy to ensure the powders were not masked by epoxy glue. The probe used was a micro-fabricated, Si-cantilever with a pyramidal tip (Oxford Instruments, Santa Barbara, CA, USA). Optical lever sensitivity calibration was established by averaging 100 force curves on a freshly cleaved mica surface [27]. The spring-constant $(k)$ of the tip ranged between $2.4-2.8 \mathrm{~N} / \mathrm{m}$. The topographical studies were performed in intermittent-contact mode (AC-mode) in air. For topography, the surface was scanned for $10 \mu \mathrm{m} \times 10 \mu \mathrm{m}$ and $4.7 \mu \mathrm{m} \times 4.7 \mu \mathrm{m}$, with a resolution of $512 \times 512$ pixels. Image acqui- 
sition and data analysis was performed using software Asylum Research (Ver. 16.29.232) based on lgor Pro (Ver 6.32).

\subsection{Wettability and Dissolution Characteristics of Whey Protein Isolate Powders}

The wettability of WPI powders was measured gravimetrically using a modified immersional wetting approach $[28,29]$. Powder samples were poured onto ultrapure water and allowed to wet and sink for $1 \mathrm{~h}$. Powder that remained on the water surface was carefully removed with a spoon, weighted and dried overnight at $105^{\circ} \mathrm{C}$. The mass of final powder was calculated by subtracting the mass of moisture and wettability (\%) was calculated from the mass of powder remaining on the water surface. The dissolution properties were assessed based on the amount of insoluble sediment formed after rehydration of WPI powders in water. WPI powder $(6.0 \mathrm{~g})$ was added to ultrapure water $(100 \mathrm{~mL})$ at $25^{\circ} \mathrm{C}$ in a graduated centrifuge tube, together with an anti-foaming agent (Foamtech, FGA 0.1) and blended for $90 \mathrm{~s}$ in a solubility index meter using $\sim 4 \mathrm{~cm}$ diameter rotor (Labinco BV, Breda, the Netherlands). Solutions were left to disperse for $15 \mathrm{~min}$ and gently stirred with a spatula in a reproducible manner before pouring an aliquot $(50 \mathrm{~mL})$ into a graduated glass centrifuge tube. After centrifugation $(\sim 350 \times g)$ for $5 \mathrm{~min}$, the supernatant was removed, and distilled water was added to the sediment, up to the $50 \mathrm{~mL}$ line, before re-centrifugation $(5 \mathrm{~min}$ ). The amount of sediment in the final $50 \mathrm{~mL}$ solution was measured visually using graduations on the centrifuge tubes [30].

\subsection{Powder Particle Morphology, Wetting, Swelling, and Dissolution \\ 2.7.1. Scanning Electron Microscopy}

WPI powders were dried at $102{ }^{\circ} \mathrm{C}$ for $4 \mathrm{~h}$ in an oven to remove moisture. The samples were mounted on aluminum stubs using a double-sided adhesive carbon disk and sputter-coated with a thin layer of gold/palladium using a Polaron E5100 sputter coater unit (Quorum Technologies Ltd., Sussex, UK). Morphology and surface structures of the samples were observed with a FEI Quanta ${ }^{\mathrm{TM}} 200$ (FEI Company, Eindhoven, the Netherlands) scanning electron microscope (SEM) operating at $10 \mathrm{kV}$ and magnification $800 \times$. All images were captured using the integrated imaging software xT microscope control and a charge-coupled device (CCD) camera.

\subsubsection{Environmental Scanning Electron Microscopy}

For the hydration properties of WPI powders, samples were prepared and analysed based on an ESEM technique described previously by Cenini et al., [20]. Briefly, WPI powder samples were dried in an oven $\left(102{ }^{\circ} \mathrm{C}, 4 \mathrm{~h}\right)$ and stored in a sealed desiccator over a saturated aqueous solution of lithium chloride (relative humidity, $\mathrm{RH} \sim 11 \%$ at $5{ }^{\circ} \mathrm{C}$ ). Before imaging, powders were uniformly placed on double-sided carbon tape, attached to a copper stub (3205c Agar Scientific, Stansted, UK). The stub was mounted on a pre-cooled $\left(5^{\circ} \mathrm{C}\right)$ Peltier cooling stage fitted inside the microscope chamber. All observations were performed using an FEI Quanta ${ }^{\mathrm{TM}} 200$ SEM (FEI Company, Eindhoven, the Netherlands) equipped with a $500 \mu \mathrm{m}$ aperture gaseous secondary electron detector using the following parameters: accelerating voltage $10 \mathrm{kV}$, spot size 3, magnification $800 \times$, working distance $7.4 \pm 0.6 \mathrm{~mm}$ and $0.1 \mathrm{~ms}$ scanning speed, at a constant temperature of $5{ }^{\circ} \mathrm{C}$. Images were taken using xT microscope control software and a CCD camera. After the initial chamber pressure was achieved $\left(100.0 \mathrm{~Pa}, 5^{\circ} \mathrm{C}, \sim 11 \% \mathrm{RH}\right)$, the RH was increased in 5\% increments at $5 \mathrm{~min}$ intervals, starting from $15 \% \mathrm{RH}$. After reaching saturated water pressure $(906.6 \mathrm{~Pa} \geq 100 \% \mathrm{RH})$, the samples were held at this RH for $60 \mathrm{~min}$. During this time, water started to form on the stub's surface, eventually covering the sample entirely. The RH was then slowly decreased to the initial RH and the powder residue was imaged.

\subsubsection{Particle Wetting and Dissolution Analysis by Light Backscatter Analysis}

The colloidal properties of an aqueous system were measured based on the backscattering (BS) properties of samples exposed to pulsed near-infrared light $(\lambda=880 \mathrm{~nm})$, 
exploiting the principle that larger particles in a dispersion scatter light more intensely [31]. In this study, WPI powder $(0.8 \mathrm{~g})$ was dispensed onto ultrapure water $\left(20 \mathrm{~mL}, 25^{\circ} \mathrm{C}\right)$ in glass vials ( $40 \mathrm{~mm}$ height), simulating the parameters for measuring powder wettability in the GEA Niro A 5b method [29]. Measurements of BS were taken every $30 \mathrm{~s}$ over a $1 \mathrm{~h}$ period, across the vertical axis of a glass vial (scanned at every $40 \mu \mathrm{m}$ distance), utilising a Turbiscan ${ }^{\mathrm{TM}}$ LAB stability analyser (Formulaction, Toulouse, France). The acquired BS data of the powder dispersion were analysed using the integrated software package, the BS spectra were averaged and changes in BS $(\triangle \mathrm{BS})$ of spectra were calculated for each sample as given in Equation (1).

$$
\Delta \mathrm{BS}=\left(B S_{t 2}-B S_{t 1}\right) /\left(t_{2}-t_{1}\right)
$$

where, BS is backscattering at the given time $\left(t_{1}=0, t_{2}=60 \mathrm{~min}\right)$.

As a comparator for the dispersibility of WPI powder for all treatments, a fully dissolved WPIc sample (WPI $\mathrm{D}_{\mathrm{D}}, 4 \%$ total solids) was used as a reference. Wetting properties were compared from the spectral region at the top $10 \mathrm{~mm}$ segment (40-31 $\mathrm{mm}$ height), while for dissolution properties, the spectral region of the segment between 30 to $0 \mathrm{~mm}$ was analysed.

\subsubsection{Acoustic Resonance Dissolution Spectroscopy for Occluded Gas Release}

The dissolution properties of WPI powders were assessed using a real-time recording of the changes in gas release from WPI powder samples during rehydration using Broadband Acoustic Resonance Dissolution Spectroscopy (BARDS; BARDS Research Centre, University College Cork, Cork, Ireland). BARDS measures the changes in sound frequency $(0-20 \mathrm{kHz})$ in the presence of air bubbles that are released from powder particles during rehydration. The samples were prepared as described by Vos et al. [21]; briefly, the steadystate frequency of agitated ultrapure water $(25 \mathrm{~mL})$ at $\sim 20^{\circ} \mathrm{C}$ was measured for $30 \mathrm{~s}$ before $0.05 \mathrm{~g}(0.2 \%$ total solids) of powder was poured onto the water surface which was stirred at a constant rate to create a gentle vortex. The measurement is considered complete when the occluded gas escapes from the solvent and the sound frequency returns to the initial steady state. Extraction of frequency data from fixed time points based on the total time of the trial was carried out using the BARDS $0.9 \mathrm{v}$ software [8].

\subsubsection{Measurement of Ion Release from Powder Particles}

The release of ions in the dispersant solution during powder rehydration was assessed by monitoring conductivity of the solution using a conductivity probe connected to a Titrando auto titrator (Metrohm Ireland Ltd., Athy Road, Co. Carlow, Ireland) at $25^{\circ} \mathrm{C}$. Powder was dispersed at the rate of $1.25 \%$ TS $(w / v)$ into $300 \mathrm{~mL}$ of ultrapure water, with the impeller speed adjusted to avoid vortex and foam formation. Conductivity was measured at $2 \mathrm{~s}$ intervals over $50 \mathrm{~min}$ [32].

\subsection{Data Analysis}

Spray-dried powders were manufactured and sample analysis was conducted in triplicate. Where applicable, the data generated were subjected to one-way ANOVA to determine statistically significant differences at a 95\% confidence level $(p<0.05)$ using Microsoft Excel. A Tukey's honesty significant difference test was used for sample comparison. Results are expressed as mean \pm standard deviation, with statistically significant differences identified using superscript letters.

\section{Results and Discussion}

\subsection{Powder Chemical, Bulk and Surface Composition}

In an effort to specifically study the influence of nanoparticulation on physical and rehydration properties of the WPI powders, it was important that all powders had similar composition. The protein $(w / w)$ percent of WPIc, $\mathrm{WPI}_{\mathrm{UH}}, \mathrm{WPI}_{\mathrm{H}}$ and $\mathrm{WPI}_{\mathrm{HCa}}$ was $94.6 \pm 1.61,89.5 \pm 0.21,90.6 \pm 0.08$, and $91.3 \pm 1.39$, respectively, while their moisture content was $3.81 \pm 0.22,5.0 \pm 0.41,6.28 \pm 0.42$, and $5.30 \pm 0.20 \%$. The extent of whey 
protein denaturation in $\mathrm{WPI}_{\mathrm{UH}}, \mathrm{WPI}_{\mathrm{H}}$ and $\mathrm{WPI}_{\mathrm{HCa}}$ was $3.20,64.4$ and $74.4 \%$, while the size of whey protein particles/aggregates in solution was $7 \pm 5.4 \mathrm{~nm}$ for $\mathrm{WPI}_{\mathrm{C}}$ and $\mathrm{WPI}_{\mathrm{UH}}$, $114 \pm 8.3 \mathrm{~nm}$ for $\mathrm{WPI}_{\mathrm{H}}$ and $132 \pm 6.7 \mathrm{~nm}$ for $\mathrm{WPI}_{\mathrm{HCa}}$, as a result of denaturation and aggregation [23]. The respective levels of denaturation of $\alpha$-lactalbumin in the samples were $2.20,44.5$ and $54.8 \%$, while the corresponding values for $\beta$-lactoglobulin were 3.60 , 70.8 and $80.7 \%$ [23].

Nanoparticulation of whey proteins influenced the elemental composition (carbon, nitrogen, oxygen, calcium) of the surface of the subsequent powders (Table 1). The oxygen content (\%) of $\mathrm{WPI}_{\mathrm{UH}}(17.3), \mathrm{WPI}_{\mathrm{H}}(17.4)$ and $\mathrm{WPI}_{\mathrm{HCa}}$ (17.5) were similar, while the oxygen content was significantly lower $(p<0.05)$ in $\mathrm{WPI}_{C}(15.3)$ than in the other powders. The carbon content (\%) of $\mathrm{WPI}_{\mathrm{H}}(67.4), \mathrm{WPI}_{\mathrm{HCa}}(67.2)$ and $\mathrm{WPI}_{\mathrm{UH}}(66.9)$ was similar, whereas $\mathrm{WPI}_{C}(69.7)$ had significantly higher $(p<0.05)$ carbon content. The nitrogen and calcium contents at the surface of WPI powders were similar in heated samples $\left(\mathrm{WPI}_{\mathrm{H}}\right.$ and $\left.\mathrm{WPI}_{\mathrm{HCa}}\right)$, while the contents in unheated samples $\left(\mathrm{WPI}_{\mathrm{C}}\right.$ and $\left.\mathrm{WPI}_{\mathrm{UH}}\right)$ were significantly lower $(p<0.05)$. The results from the current study indicate that thermal treatment $\left(\mathrm{WPI}_{\mathrm{H}}\right.$ vs. $\mathrm{WPI}_{\mathrm{UH}}$ ) altered the proportion of nitrogen and calcium at the surface of WPI powders, whereas there was no evidence of such an effect on increasing calcium content $\left(\mathrm{WPI}_{\mathrm{H}} \mathrm{vs}\right.$. $\mathrm{WPI}_{\mathrm{HC}}$; Table 1). This suggests that heat-induced aggregation of whey proteins altered the surface composition of resultant powders because more nitrogenous materials (protein) were concentrated at the powder surface. A previous study based on spray-dried WPI powders demonstrated that $30 \%$ of the power particle surface was covered by lipid [7]. More nitrogenous material on the surface of the spray-dried WPI powders in the present study was probably due to larger aggregates, covering a greater proportion of total surface area of the powder, which buried minor components (lactose, fat and minerals) inside. Interestingly, the values for elemental composition in WPI powders reported in the current study were comparable to those reported in previous studies involving WPI powders $[7,33]$.

Table 1. Elemental composition of the surface (10 $\mathrm{nm}$ depth) as determined using $\mathrm{X}$-ray photoelectron spectroscopy in terms of oxygen, carbon, nitrogen, and calcium of 4 whey protein isolate powders, control $\left(\mathrm{WPI}_{\mathrm{C}}\right)$, unheated $\left(\mathrm{WPI}_{\mathrm{UH}}\right)$, heated prior to drying $\left(\mathrm{WPI}_{\mathrm{H}}\right)$ and heated with calcium prior to drying $\left(\mathrm{WPI}_{\mathrm{HCa}}\right)$.

\begin{tabular}{ccccc}
\hline & \multicolumn{3}{c}{ Relative Atomic Concentrations (\%) } \\
\hline Powder & Oxygen & Carbon & Nitrogen & Calcium \\
\hline $\mathrm{WPI}_{\mathrm{C}}$ & $15.3 \pm 0.4^{\mathrm{b}}$ & $69.7 \pm 0.6^{\mathrm{a}}$ & $13.5 \pm 0.6^{\mathrm{b}}$ & $0.0^{\mathrm{b}}$ \\
$\mathrm{WPI}_{\mathrm{UH}}$ & $17.3 \pm 0.3^{\mathrm{a}}$ & $66.9 \pm 0.4^{\mathrm{b}}$ & $13.3 \pm 0.4^{\mathrm{b}}$ & $0.0^{\mathrm{b}}$ \\
$\mathrm{WPI}_{\mathrm{H}}$ & $17.4 \pm 0.3^{\mathrm{a}}$ & $67.4 \pm 0.4^{\mathrm{b}}$ & $14.1 \pm 0.1^{\mathrm{a}}$ & $0.3 \pm 0.1^{\mathrm{a}}$ \\
$\mathrm{WPI}_{\mathrm{HCa}}$ & $17.5 \pm 0.3^{\mathrm{a}}$ & $67.2 \pm 0.4^{\mathrm{b}}$ & $14.1 \pm 0.4^{\mathrm{a}}$ & $0.2^{\mathrm{a}} \pm 0.1^{\mathrm{a}}$ \\
\hline
\end{tabular}

$\overline{\mathrm{a}, \mathrm{b}}$ Means with different superscript letters within same column are significantly different $p<0.05$.

\subsection{Powder Surface Structure}

The morphological characteristics of WPI powders were reported in a previous study, showing powder particles in $\mathrm{WPI}_{C}$ and $\mathrm{WPI}_{\mathrm{UH}}$ to be smooth, while powder particles in $\mathrm{WPI}_{\mathrm{H}}$ and $\mathrm{WPI}_{\mathrm{HCa}}$ had more shallow protrusions and broken structures [23]. Noteably, differences between $\mathrm{WPI}_{\mathrm{C}}$ and $\mathrm{WPI}_{\mathrm{UH}}$ were expected to be minimal, as both powders did not contain nanoparticulated whey proteins, with the powders differing only in the scale of drying technology used (i.e., industrial- and pilot-scale, respectively). In-depth topographical scans in two dimensions (amplitude image) and three dimensions (height image) on the powder particle surface obtained from AFM are shown in Figure 1. Topographical scans at $4 \mu \mathrm{m}^{2}$ resolution revealed $\mathrm{WPI}_{\mathrm{C}}$ and $\mathrm{WPI}_{\mathrm{HCa}}$ particles displayed micro wrinkles, $\mathrm{WPI}_{\mathrm{H}}$ had both micro wrinkles and protrusions, while $\mathrm{WPI}_{\mathrm{UH}}$ had a relatively smooth surface (Figure 1A,C); these results were confirmed with analysis of section lines of each sample (data not shown). The root mean square width of wrinkles (roughness) of $\mathrm{WPI}_{\mathrm{C}}, \mathrm{WPI}_{\mathrm{UH}}$, $\mathrm{WPI}_{\mathrm{H}}$, and $\mathrm{WPI}_{\mathrm{HCa}}$, was approximately $4.35 \pm 1.24 \mathrm{~nm}, 0.35 \pm 0.28 \mathrm{~nm}, 6.20 \pm 2.4 \mathrm{~nm}$, and 
$5.57 \pm 1.92 \mathrm{~nm}$, respectively. The results showed that the surface roughness of WPI powder particles was affected by the level of whey protein nanoparticulation, although it is less clearly discernible in the images (Figure 1).

(A)

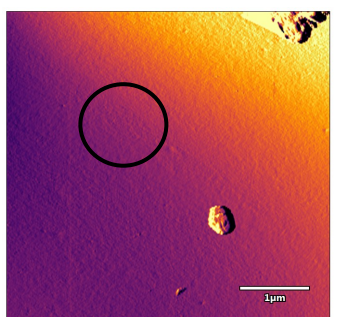

$\mathrm{WPI}_{\mathrm{C}}$

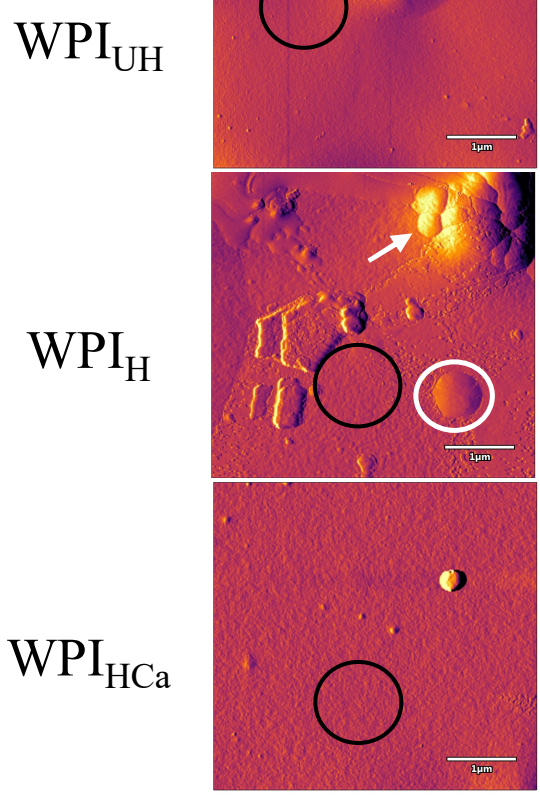

(B)
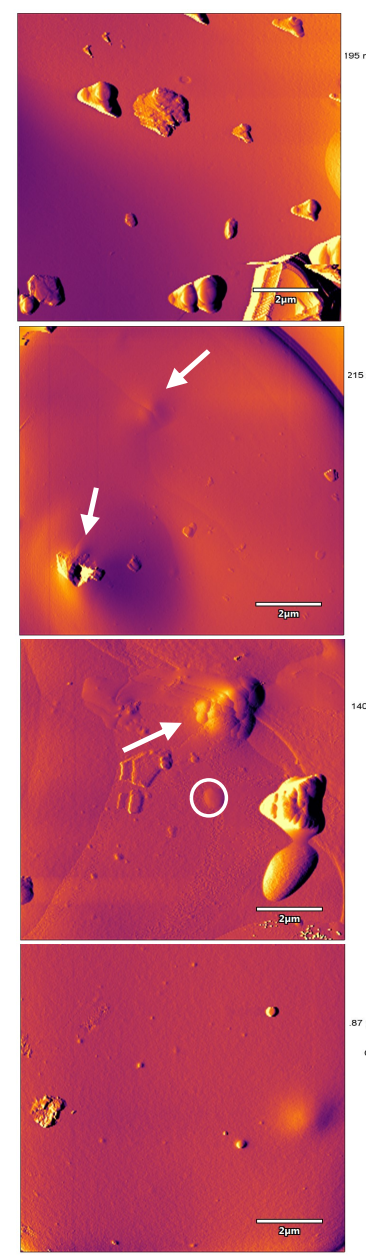

(C)
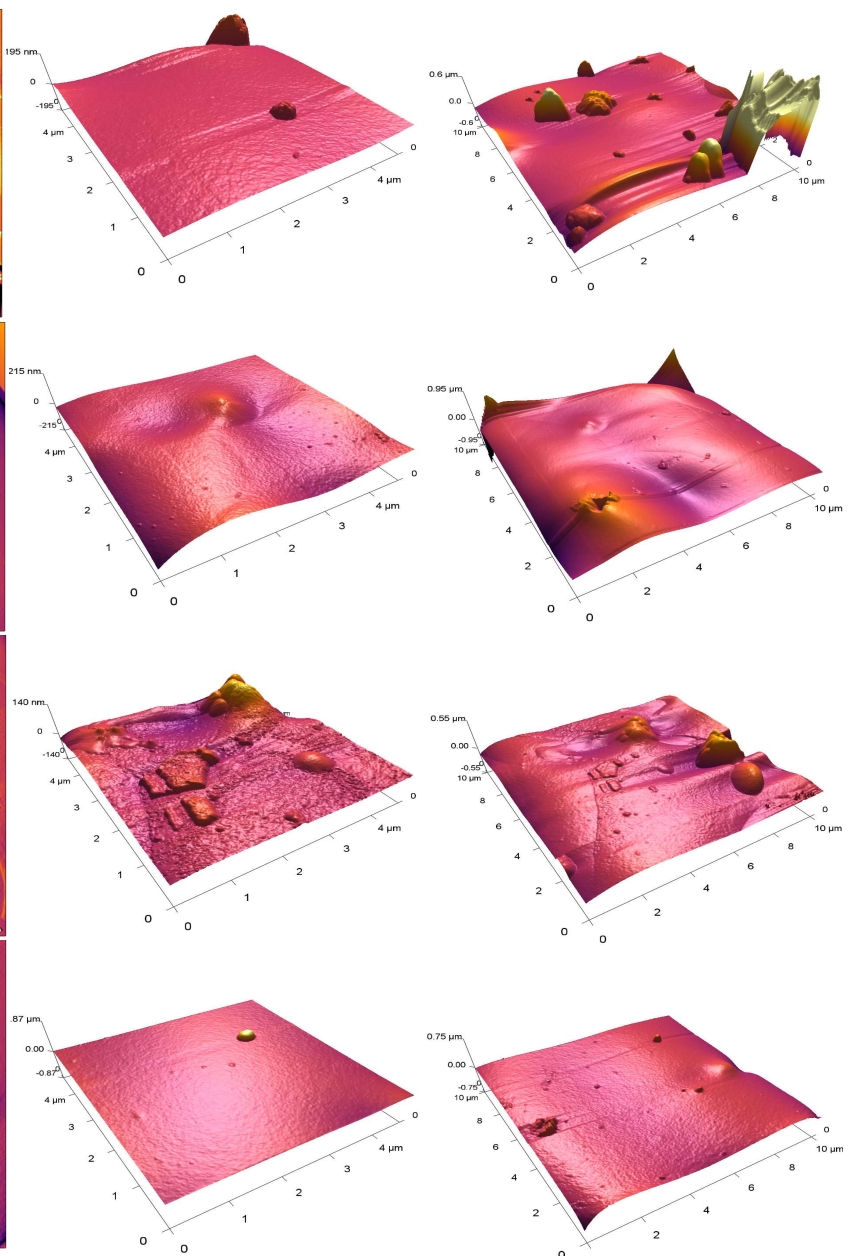

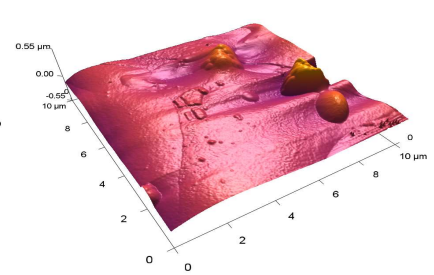

(D)
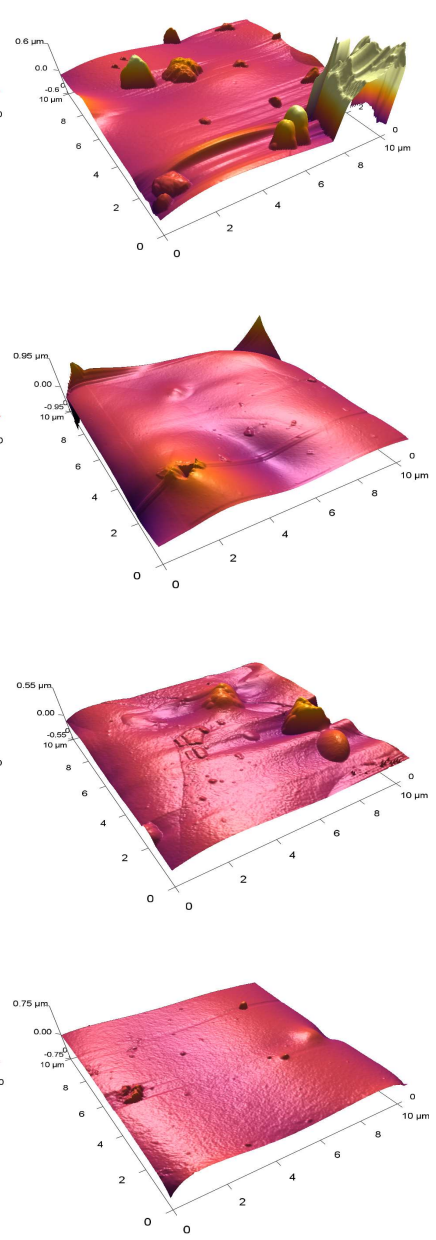

Figure 1. Topographical scans of WPI powders using AFM. All micrographs are composed of 512 scan points and 512 scan lines with both amplitude and height micrographs having an area of $4.7 \mu \mathrm{m} \times 4.7 \mu \mathrm{m}(\mathbf{A}, \mathbf{C})$ or $10 \mu \mathrm{m} \times 10 \mu \mathrm{m}(\mathbf{B}, \mathbf{D})$ observation window, respectively, of four WPI powders: the control (WPI $\mathrm{I}_{\mathrm{C}}$ ), unheated $\left(\mathrm{WPI}_{\mathrm{UH}}\right)$, heated before drying $\left(\mathrm{WPI}_{\mathrm{H}}\right)$ and heated with $2.5 \mathrm{mM}$ of calcium prior to drying $\left(\mathrm{WPI}_{\mathrm{HCa}}\right)$. The white arrows and circles indicate protrusion-like structures. Black circles show the area of wrinkles.

The differences were more apparent at $10 \mu \mathrm{m}^{2}$, whereby $\mathrm{WPI}_{\mathrm{C}}$ particles had smooth surfaces and protrusions, $\mathrm{WPI}_{\mathrm{UH}}$ had smooth surfaces, $\mathrm{WPI}_{\mathrm{H}}$ had a mix of smooth surfaces, micro wrinkles, extensive cracks and protrusions (as reported by Burgain et al. [10]), whereas $\mathrm{WPI}_{\mathrm{HCa}}$ had more micro wrinkles and an apparent lack of any smooth areas on the surface (Figure 1B,D). The results presented in the current study show that spherical protrusions appeared embedded on $\mathrm{WPI}_{\mathrm{H}}$ (Figure $1 \mathrm{~A}, \mathrm{~B}$, white circles), indicative of the formation of non-uniform structures during the drying process. It also demonstrates that the thermal treatment used induced the formation of micro wrinkles, and that the addition of calcium inhibited the formation of such protrusions. Nanoparticulation of whey proteins resulted in wrinkled surface microstructures in the subsequent WPI powders, similar to those reported by Burgain et al. [10], who investigated the effect of heat and aging on WPI powder surface structures. The AFM and XPS analysis showed that WPI powder prepared 
from nanoparticulated whey proteins, through heat- and mineral-induced aggregation, results in the surface being more dense with protein components, which could play a key role in the rehydration properties of these powders.

\subsection{Rehydration Characteristics of WPI Powder}

\subsubsection{Powder Wetting and Dissolution}

The results for wetting (proportion of powder particles that did not sink in ultrapure water at ambient temperature over $1 \mathrm{~h}$ ) and dissolution characteristics of the WPI powders, as influenced by nanoparticulation of whey proteins, are shown in Table 2. Unheated samples $\left(\mathrm{WPI}_{\mathrm{UH}}\right.$ and $\mathrm{WPI}_{\mathrm{C}}$ ) wetted faster $(99.9 \%$ and $66.5 \%$, respectively) than heated samples $\left(\mathrm{WPI}_{\mathrm{H}}\right.$ and $\left.\mathrm{WPI}_{\mathrm{HCa}}\right)$, with wettability being 19.1 and $12.5 \%$, respectively, indicating that nanoparticulation of whey proteins as a result of thermal treatment and calcium addition led to the powders having poor wetting properties. Dairy powders generally display poor wettability characteristics when hydrophobic components are concentrated at the powder particle surface, limiting water permeation into the powder particle [6]. The significantly poorer wetting properties of powders prepared with nanoparticulated whey proteins was likely due to unfolding of hydrophobic protein domains at the surface of the aggregates as a result of denaturation. Nanoparticulation of whey proteins has previously been shown to confer enhanced techno-functional properties, in particular higher heat stability (with associated benefits for thermal processing), on whey protein solutions, arising from the modulation of protein-protein interactions [12].

Table 2. Wettability and insolubility measurements in ultrapure water dynamically over $50 \mathrm{~min}$ at $25{ }^{\circ} \mathrm{C}$ for whey protein isolate powders, original $\mathrm{WPI}\left(\mathrm{WPI} \mathrm{C}_{\mathrm{C}}\right)$, unheated $\left(\mathrm{WPI}_{\mathrm{UH}}\right)$, heated $\left(\mathrm{WPI}_{\mathrm{H}}\right)$ and heated with calcium prior to drying $\left(\mathrm{WPI}_{\mathrm{HCa}}\right)$.

\begin{tabular}{ccc}
\hline WPI Powders & Wetting $(\% w / w)$ & Insolubility Measurement $(\mathrm{mL} / 50 \mathrm{~mL})$ \\
\hline WPI $_{\mathrm{C}}$ & $66.5 \pm 2.5^{\mathrm{b}}$ & $<0.1$ \\
WPI $_{\mathrm{UH}}$ & $99.9 \pm 0.1^{\mathrm{a}}$ & $<0.1$ \\
$\mathrm{WPI}_{\mathrm{H}}$ & $19.1 \pm 1.6^{\mathrm{c}}$ & $<0.1$ \\
WPI $_{\mathrm{HCa}}$ & $12.5 \pm 1.6^{\mathrm{c}}$ & 0.2 \\
\hline${ }^{a-c}$ Means with different superscript letters within same column are significantly different $p<0.05$.
\end{tabular}

On the other hand, the insolubility characteristics of $\mathrm{WPI}_{\mathrm{C}}, \mathrm{WPI}_{\mathrm{UH}}$ and $\mathrm{WPI}_{\mathrm{H}}$ were similar, with the volume of insoluble material being less than $0.1 \mathrm{~mL} / 50 \mathrm{~mL}$ in solution, whereas this was slightly higher $(0.2 \mathrm{~mL} / 50 \mathrm{~mL})$ for $\mathrm{WPI}_{\mathrm{HCa}}$ than the other WPI powders. The current study showed that heat and mineral-induced aggregation of whey proteins prior to drying resulted in a slightly higher proportion of insoluble material during powder dissolution (Table 2). However, such small differences in insolubility are likely to have minimal effects on the overall dissolution performance of the different WPI powders produced in the present work.

\subsubsection{Powder Particle Hydration}

Using SEM, the surface microstructure of $\mathrm{WPI}_{\mathrm{C}}$ and $\mathrm{WPI}_{\mathrm{UH}}$ powder particles appeared smooth, while $\mathrm{WPI}_{\mathrm{H}}$ and $\mathrm{WPI}_{\mathrm{HCa}}$ had more shallow protrusions and broken structures (Figure 2(A1-D1)). All of the powders considered in this study showed signs of moisture sorption and slight swelling as RH increased from 11 to $100 \%$ using ESEM analysis (Figure 2(A2-D4)). Immediately after reaching $100 \% \mathrm{RH}\left(867 \mathrm{~Pa}\right.$ at $5{ }^{\circ} \mathrm{C}$, Figure 2(A4-B4)), $\mathrm{WPI}_{\mathrm{C}}$ and $\mathrm{WPI}_{\mathrm{UH}}$ particles showed a rapid change in swelling rate, and after $10 \mathrm{~min}$ of exposure at $100 \% \mathrm{RH}$, they started to dissolve, completely losing shape and definition (Figure 2(A5-B5)). In contrast, $\mathrm{WPI}_{\mathrm{H}}$ and $\mathrm{WPI}_{\mathrm{HCa}}$ particles slowly swelled at $100 \%$ $\mathrm{RH}$, and showed only a little dissolution, even at higher $\mathrm{RH}\left(>100 \%, 906.6 \mathrm{~Pa}\right.$ at $\left.5{ }^{\circ} \mathrm{C}\right)$ (Figure 2(C4,C5-D4,D5)). After $60 \mathrm{~min}$ at $>100 \% \mathrm{RH}$ (fully hydrated sample), $\mathrm{WPI}_{\mathrm{C}}$ and $\mathrm{WPI}_{\mathrm{UH}}$ had no visible particles on the formed water droplet, whereas partially dissolved $\mathrm{WPI}_{\mathrm{H}}$ and $\mathrm{WPI}_{\mathrm{HCa}}$ particles floated on top (Figure 2(A6-D6)). When the RH was returned 
to $11 \% \mathrm{RH}$ (dry condition), and the resulting residue was imaged, $\mathrm{WPI}_{\mathrm{C}}$ and $\mathrm{WPI}_{\mathrm{UH}}$ had reasonably uniform residue with no visible particles (i.e., fully dissolved) (Figure 2(A7-B7)), while the residue for $\mathrm{WPI}_{\mathrm{H}}$ and $\mathrm{WPI}_{\mathrm{HCa}}$ exhibited particles with their original morphology still identifiable (Figure 2(C7-D7)). Shortening, or elimination, of swelling is generally linked to faster powder rehydration [34]. This indicates that the presence of thermal- and mineral-induced whey protein aggregates may increase the surface hydrophobicity, leading to lower accessibility of polar groups on powder surfaces for solvent to establish interactions, consequently inhibiting water uptake and hence powder particle swelling. Moreover, Hussain et al. [32] found the absence of powder swelling when secondary structures (i.e., $\alpha$-helixes) of whey proteins are denatured.

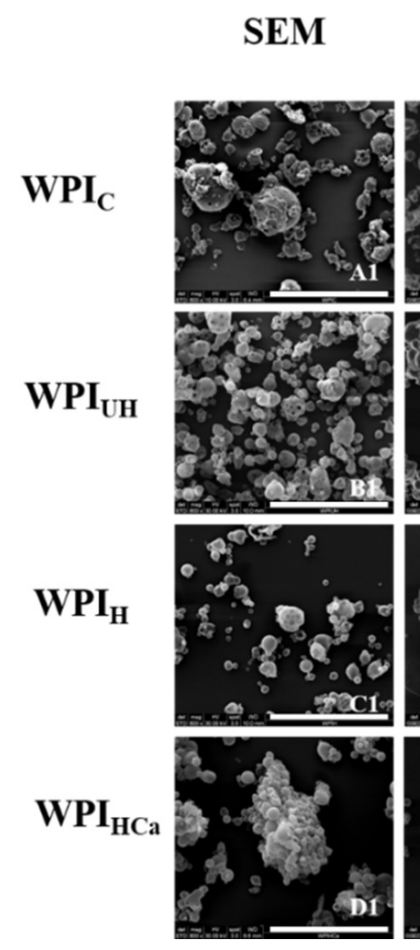

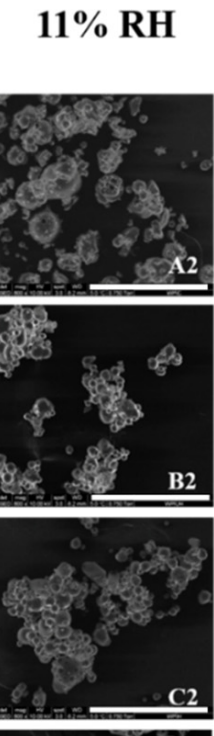
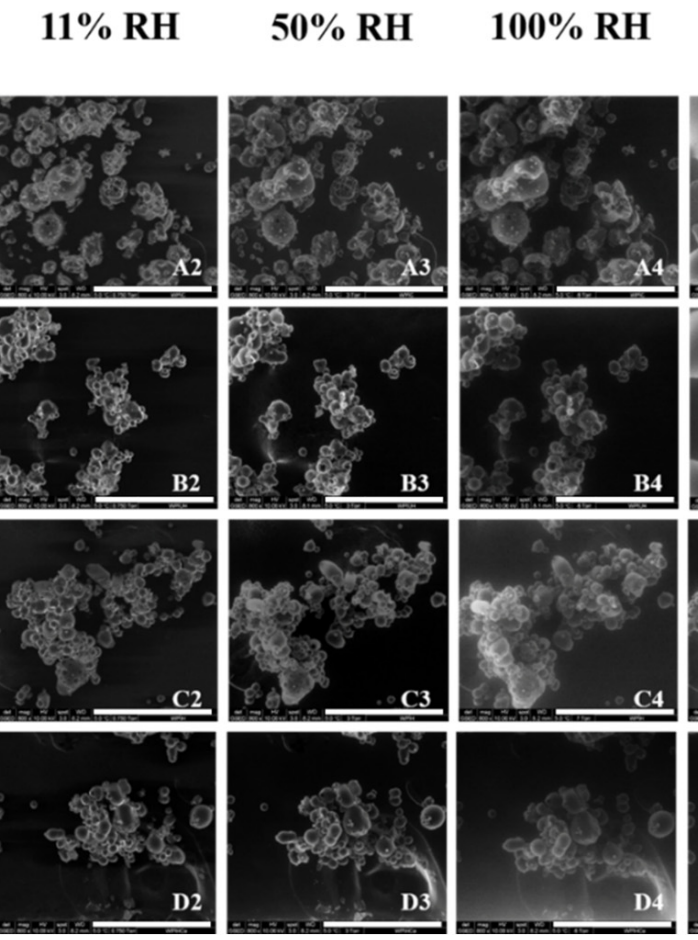

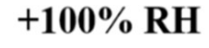

$(10$ ')
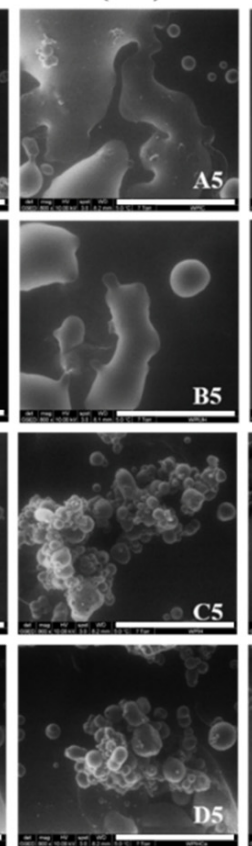

$+100 \%$ RH

(60')

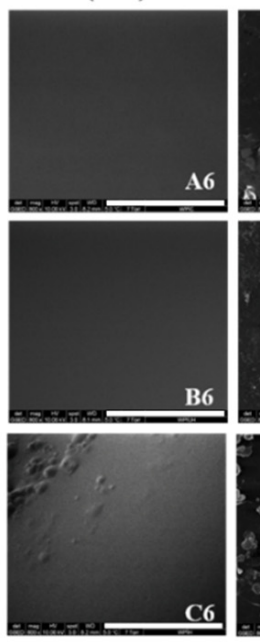

Residue
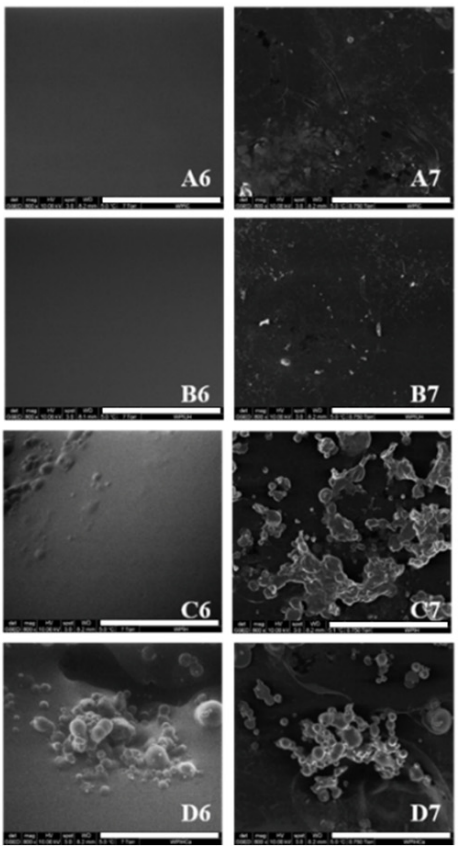

Figure 2. SEM and ESEM micrographs of whey protein powders at various relative humidities (RHs). The control (WPI ${ }_{C}$ A1-A7), unheated (WPI $\left.\mathrm{UH}_{\mathrm{H}}, \mathbf{B} 1-\mathbf{B} 7\right)$, heated to $90{ }^{\circ} \mathrm{C}$ for $30 \mathrm{~s}$ prior to drying $\left(\mathrm{WPI}_{\mathrm{H}}, \mathbf{C 1}-\mathrm{C} 7\right)$ and heated to $90{ }^{\circ} \mathrm{C}$ for $30 \mathrm{~s}$ with a $2.5 \mathrm{mM}$ calcium addition prior to drying $\left(\mathrm{WPI}_{\mathrm{HCa}}\right.$, D1-D7) samples were imaged at magnification $800 \times$ with increasing RH (from 11 to over 100\% RH). Representative RHs (11, 50, 100 and over 100\%) and the residue left after particle hydration, reconstitution and subsequent dehydration are shown. Scalebar $=200 \mu \mathrm{m}$.

\subsubsection{Particle Dissolution by Backscattering Analysis}

BS spectra and the calculated average backscattering ( $40 \mathrm{~mm}$ cell height over $1 \mathrm{~h}$ ) of $\mathrm{WPI}_{\mathrm{D}}$ and WPI powder samples for each treatment are shown in Figure 3, whereas the calculated average BS and $\triangle \mathrm{BS}$ are shown in Table 3 and Table S1, respectively. The BS spectra, and calculated average $\mathrm{BS}$ of $\mathrm{WPI}_{\mathrm{D}}$, were similar along all heights in the cell, representative of a stable dispersion after complete rehydration, similar to those reported in a previous study [35]. The $\mathrm{BS}$ of $\mathrm{WPI}_{\mathrm{C}}, \mathrm{WPI}_{\mathrm{UH}}$ and $\mathrm{WPI}_{\mathrm{HCa}}$ were similar within the 31-40 mm region, whereas $\mathrm{WPI}_{\mathrm{H}}$ was lower $(p<0.05)$ compared to other WPI powders. As time progressed, the average $\mathrm{BS}$ of $\mathrm{WPI}_{\mathrm{C}}$ and $\mathrm{WPI}_{\mathrm{UH}}$ became more similar to that of $\mathrm{WPI}_{\mathrm{D}}$ in all regions, whereas $\mathrm{WPI}_{\mathrm{H}}$ and $\mathrm{WPI}_{\mathrm{HCa}}$ remained significantly higher $(p<0.05)$ (Figure $3 \mathrm{~F}-\mathrm{I})$. In general, after $1 \mathrm{~h}$, the average BS and $\triangle \mathrm{BS}$ of $\mathrm{WPI}_{\mathrm{C}}$ (Figure $3 \mathrm{~B}, \mathrm{G})$ and $\mathrm{WPI}_{\mathrm{UH}}$ (Figure $\left.3 \mathrm{C}, \mathrm{H}\right)$ was significantly lower $(p<0.05)$, while the spectra of $\mathrm{WPI}_{\mathrm{H}}$ (Figure 3D,I) and $\mathrm{WPI}_{\mathrm{HCa}}$ (Figure 3E,J) remained comparable to those for $\mathrm{WPI}_{\mathrm{D}}$ (Figure $3 \mathrm{~A}, \mathrm{~F}$ ) in all regions. Large standard deviation values in the $31-40 \mathrm{~mm}$ region resulted from the large concentration of powder at and near the surface of the water, 
contributing to a large amount of light being backscattered. Taken together, these data indicate that $\mathrm{WPI}_{\mathrm{H}}$ and $\mathrm{WPI}_{\mathrm{HCa}}$ powders had significantly $(p<0.05)$ inhibited particle migration from the top of the cell towards the bottom due to poor wettability characteristics. Moreover, the $\triangle \mathrm{BS}$ of $\mathrm{WPI}_{\mathrm{C}}$ and $\mathrm{WPI}_{\mathrm{UH}}$ were negative in all regions (Table S1), and this is associated with the clarification (a type of particle migration from high to low concentration areas) of the solution, as shown in the work of Matsumiya et al. [36]. In this study, clarification can be related to wetting in the $31-40 \mathrm{~mm}$ region, and dissolution in all other regions. Comparing the $\mathrm{BS}$ of $\mathrm{WPI}_{\mathrm{D}}$ at $1 \mathrm{~h}$, it is evident that $\mathrm{WPI}_{C}$ and $\mathrm{WPI}_{U H}$ wetted and dispersed more quickly than $\mathrm{WPI}_{\mathrm{H}}$ and $\mathrm{WPI}_{\mathrm{Hca}}$, as indicated by the lower values of $\% \mathrm{BS}$ in the former samples (Table 3). It is clear from the results presented in the current study that the denatured and aggregated whey proteins at the WPI powder surface retarded sinking, likely due to poor instantaneous swelling and wetting properties.

\subsubsection{Gas Release from WPI Powders during Rehydration}

The acoustic frequency profiles of $\mathrm{WPI}_{\mathrm{C}}, \mathrm{WPI}_{\mathrm{UH}}, \mathrm{WPI}_{\mathrm{H}}$ and $\mathrm{WPI}_{\mathrm{HCA}}$ powder samples dissolved in ultrapure water are shown in Figure 4. In all dispersions, the frequency dropped to a minimum and slowly increased to the original steady-state, following the trend typically observed with dairy powders during rehydration [21,22]. The frequency drop was minimal for the $\mathrm{WPI}_{\mathrm{UH}}$ dispersion $\left(9.7\right.$ to $9.4 \mathrm{KHz}$ ), while $\mathrm{WPI}_{\mathrm{C}}$ and $\mathrm{WPI}_{\mathrm{H}}$ exhibited slightly greater frequency drops $(9.6$ to $8.7 \mathrm{KHz})$, with $\mathrm{WPI}_{\mathrm{Hca}}$ displaying a significant frequency drop (9.6 to $5.08 \mathrm{KHz}$ ) (Figure 4). The frequency drop observed in the powder dispersions was due to the release of occluded and interstitial air in the dispersion, which is a balance between gas release from powder into the liquid and gas escape from liquid to the air [21]. The results show that $\mathrm{WPI}_{\mathrm{UH}}, \mathrm{WPI}_{\mathrm{C}}$ and $\mathrm{WPI}_{\mathrm{H}}$ had a relatively low volume of gas compared to $\mathrm{WPI}_{\mathrm{HCa}}$, as shown by a greater extent of frequency drop in the latter sample (Figure 4). The minimal frequency for samples WPI $\mathrm{C}_{C}$ $\mathrm{WPI}_{\mathrm{UH}}, \mathrm{WPI}_{\mathrm{H}}$ and $\mathrm{WPI}_{\mathrm{HCA}}$ was reached at 60, 80, 191 and $273 \mathrm{~s}$, respectively, suggesting powders prepared with nanoparticulated whey proteins exhibited slower rates of gas diffusion into water, which is in agreement with the powder wettability characteristics. The acoustic frequency profiles demonstrate that nanoparticulation of whey proteins with heat and calcium prior to drying results in WPI powders with more occluded gas, possibly influencing the wettability, as occluded gas probably restricts water uptake in powder. This phenomenon may be explained by inward diffusion of a solvent through capillary networks, requiring replacement of occluded air; for powders containing higher levels of occluded air, capillary action could be retarded leading to slow wetting and sinking.

Table 3. Average backscattering (\%) of whey protein isolate (WPI) in deionized water at $25{ }^{\circ} \mathrm{C}$ measured after $1 \mathrm{~h}$ across the vertical axis of $40 \mathrm{~mm}$ cell. The samples are fully dispersed WPI solution $\left(\mathrm{WPI}_{\mathrm{D}}\right)$, original control $\left(\mathrm{WPI}_{\mathrm{C}}\right)$ powder, WPI powder prepared without heat treatment $\left(\mathrm{WPI}_{\mathrm{UH}}\right)$, nanoparticulated powders prepared by heating prior to drying $\left(\mathrm{WPI}_{\mathrm{H}}\right)$ or heated with calcium prior to drying ( $\left.\mathrm{WPI}_{\mathrm{HCa}}\right)$.

\begin{tabular}{cccccc}
\hline Cell Height & WPI $_{\mathbf{D}}$ & WPI $_{\mathbf{C}}$ & WPI $_{\mathbf{U H}}$ & WPI $_{\mathbf{H}}$ & WPI $_{\mathbf{H C a}}$ \\
\hline $0-10 \mathrm{~mm}$ & $5.7 \pm 1.03$ & $6.3 \pm 1.28$ & $7.4 \pm 1.68$ & $10.6 \pm 2.69$ & $11.3 \pm 3.09$ \\
$11-20 \mathrm{~mm}$ & $5.7 \pm 0.05$ & $6.4 \pm 0.08$ & $7.5 \pm 0.08$ & $11.0 \pm 0.10$ & $11.6 \pm 0.17$ \\
$21-30 \mathrm{~mm}$ & $5.6 \pm 0.04$ & $6.4 \pm 0.09$ & $7.4 \pm 0.07$ & $10.9 \pm 0.11$ & $11.6 \pm 0.11$ \\
$31-40 \mathrm{~mm}$ & $5.1 \pm 1.25$ & $8.8 \pm 2.43$ & $7.2 \pm 1.58$ & $11.0 \pm 6.20$ & $17.1 \pm 13.37$ \\
\hline
\end{tabular}



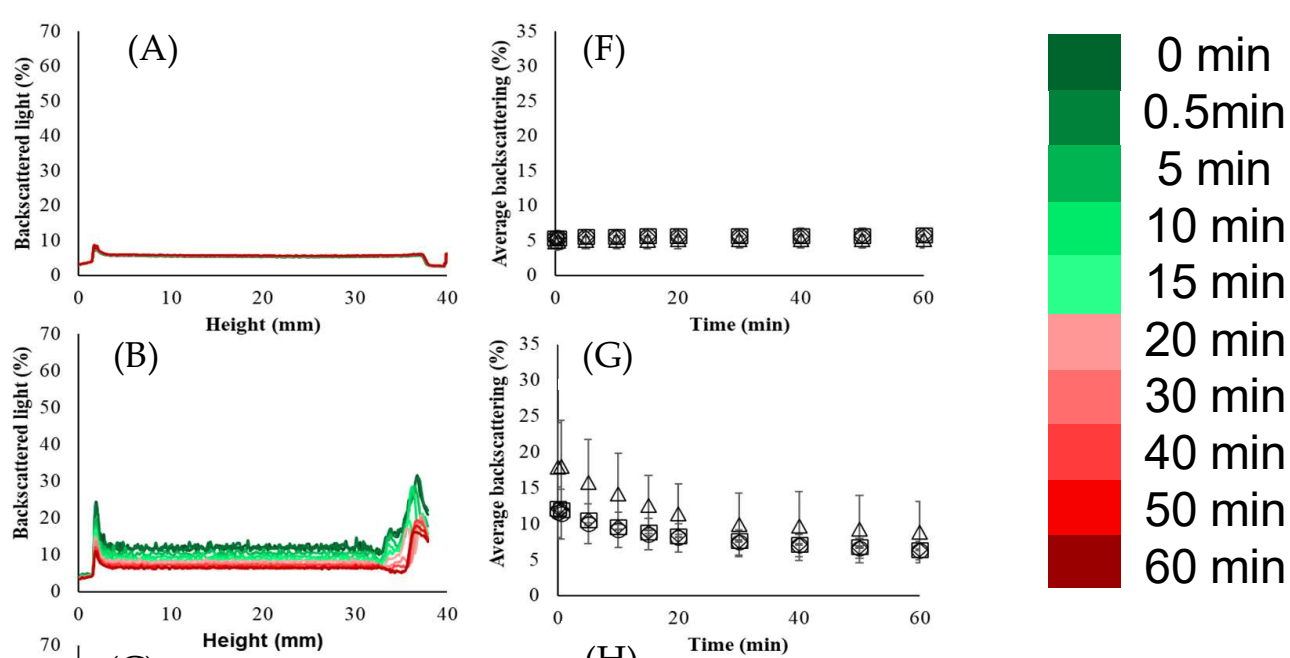

$20 \mathrm{~min}$

$30 \mathrm{~min}$

$40 \mathrm{~min}$

$50 \mathrm{~min}$
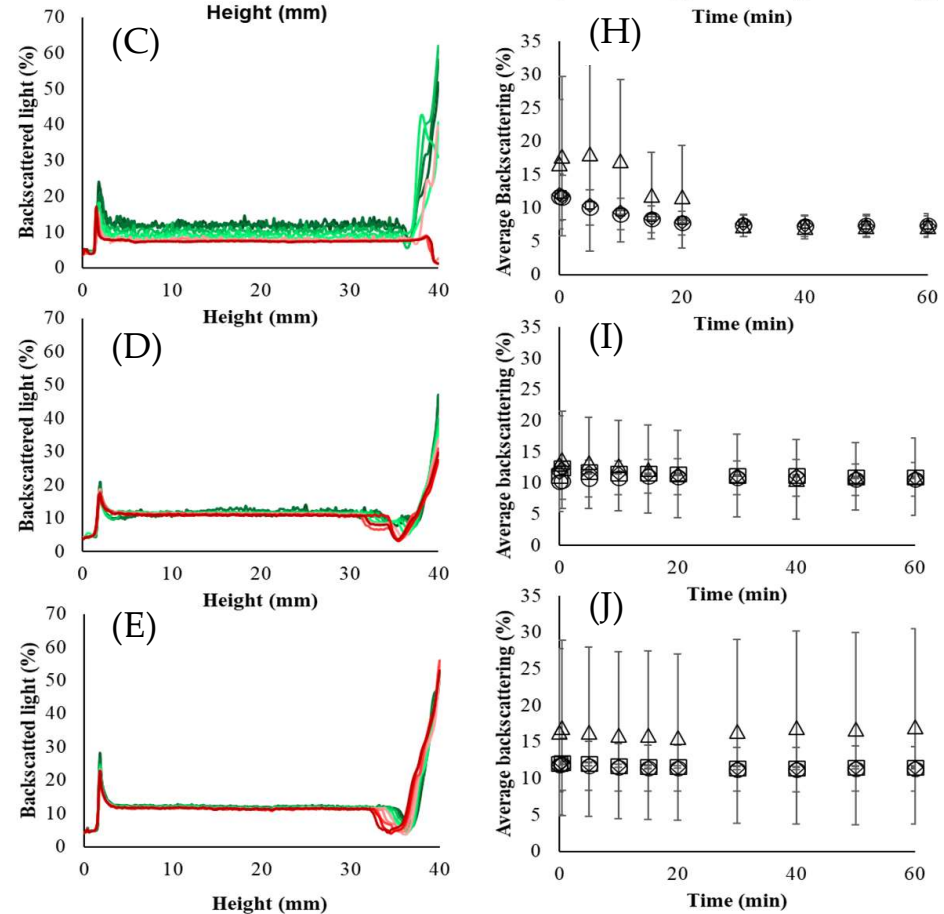

Figure 3. Raw backscatter spectrogram and regional average backscattering of a dissolved whey protein isolate $\left(\mathrm{WPI}_{\mathrm{D}}: \mathbf{A}\right)$ as a benchmark and four WPI powders: the control $\left(\mathrm{WPI}_{C}: \mathbf{B}\right)$, unheated $\left(\mathrm{WPI}_{\mathrm{UH}}: \mathbf{C}\right)$, heated prior to drying $\left(\mathrm{WPI}_{\mathrm{H}}: \mathbf{D}\right)$ and heated with calcium prior to drying $\left(\mathrm{WPI}_{\mathrm{HCa}}: \mathbf{E}\right)$ with the corresponding backscattered light averages $\mathrm{WPI}_{\mathrm{D}}(\mathbf{F}), \mathrm{WPI}_{\mathrm{C}}(\mathbf{G}), \mathrm{WPI}_{\mathrm{UH}}(\mathbf{H}), \mathrm{WPI}_{\mathrm{H}}(\mathbf{I})$ and $\mathrm{WPI}_{\mathrm{HCa}}(\mathrm{J})$ at $4 \%$ total solids measured dynamically in deionized water at $25^{\circ} \mathrm{C}$, over a $1 \mathrm{~h}$ period. The regions are: 0-10 $\mathrm{mm}(\bigcirc), 11-20 \mathrm{~mm}(\square), 21-30 \mathrm{~mm}(\diamond)$ and 31-40 $\mathrm{mm}(\triangle)$. 


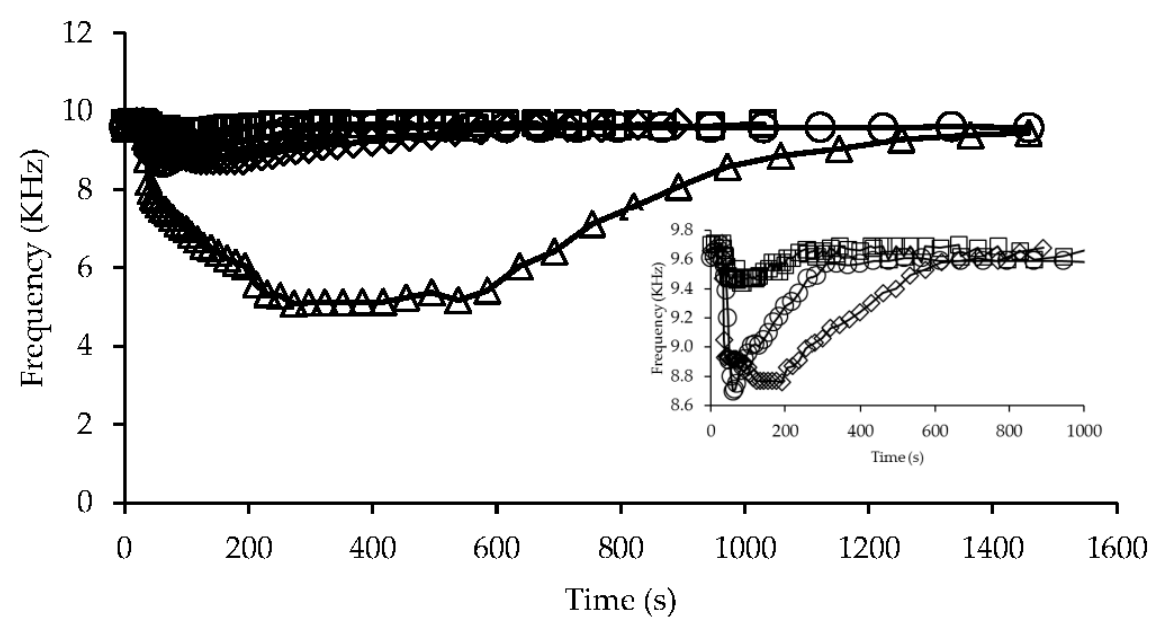

Figure 4. Comparison of frequency spectra in the dispersion of whey protein isolate powders, control $\left(\mathrm{WPI}_{\mathrm{C}} ; \bigcirc\right)$, unheated $\left(\mathrm{WPI}_{\mathrm{UH}} ; \square\right)$, heated prior to drying $\left(\mathrm{WPI}_{\mathrm{H}} ; \diamond\right)$ and heated with calcium prior to drying $\left(\mathrm{WPI}_{\mathrm{HCa}} ; \triangle\right)$ dissolved in $25 \mathrm{~mL}$ of ultrapure water at $20^{\circ} \mathrm{C}$ with a sample concentration of $0.2 \%(w / v)$, using Broadband Acoustic Resonance Dissolution (BARDS) spectroscopy. The insert shows the spectra without $\mathrm{WPI}_{\mathrm{Hca}}$ sample.

\subsubsection{Mineral Release from WPI Powders}

Conductivity in the dilute high-protein solutions with low ionic strength is mainly contributed due to anion and cation species [32]. The conductivity values of the WPI powder dispersions (indicative of mineral release) during the rehydration process increased initially and then remained in a steady-state (Figure 5). The dispersions of $\mathrm{WPI}_{\mathrm{C}}, \mathrm{WPI}_{\mathrm{UH}}$ and $\mathrm{WPI}_{\mathrm{Hca}}$ exhibited fairly similar increases in conductivity, then remained in a steady state after $15 \mathrm{~min}$, whereas the dispersion of $\mathrm{WPI}_{\mathrm{H}}$ showed a much slower increase in conductivity initially, taking $30 \mathrm{~min}$ to reach equilibrium. The slower rate of increase in conductivity for $\mathrm{WPI}_{\mathrm{H}}$ dispersions, compared to $\mathrm{WPI}_{\mathrm{UH}}$, was possibly due to heat treatment applied during nanoparticulation, attributable to increased heat-induced protein-mineral interactions. Jambraka et al. [37] also studied the rehydration properties of WPI powders using ion release data from conductimetry and found lower conductivity values of WPI or WPC solutions when ultrasonicated, which provided an example for lower conductivity values possibly due to ion pairing and shielding with oppositely charged species.

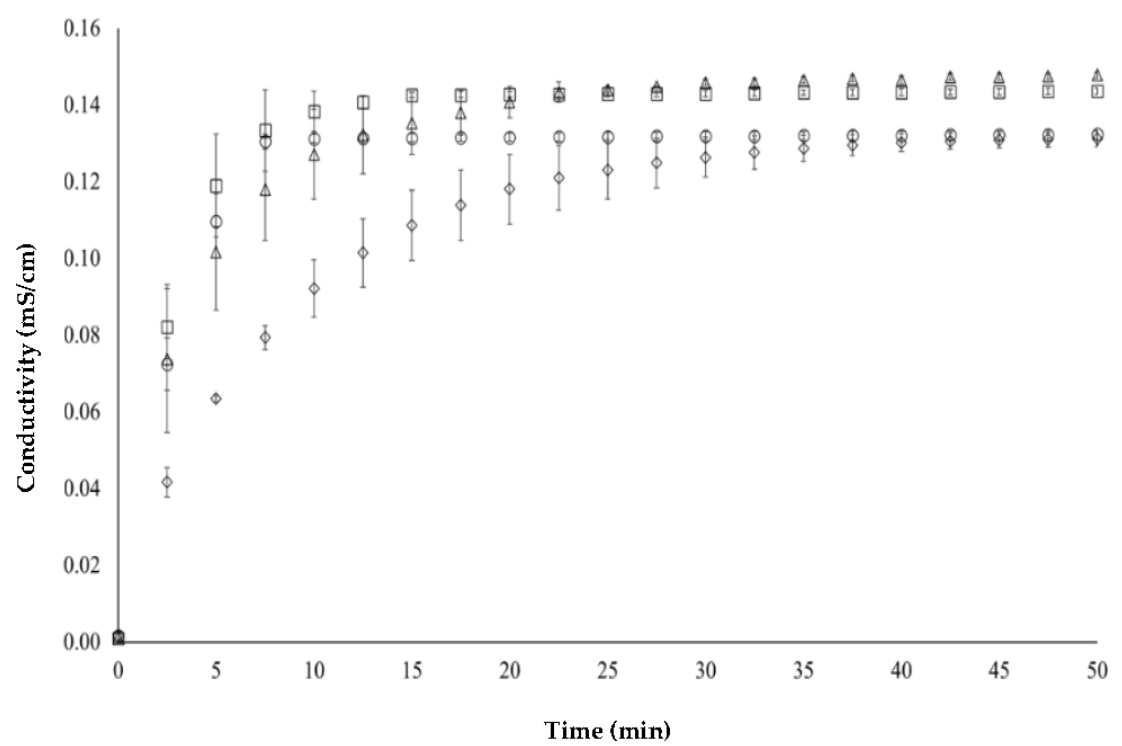

Figure 5. Conductivity during rehydration of whey protein isolate powders in ultrapure water over 
50 min at $25^{\circ} \mathrm{C}$ for control $\left(\mathrm{WPI}_{\mathrm{C}} ; \bigcirc\right)$, unheated (WPI $\left.\mathrm{UH}_{\mathrm{H}} ; \square\right)$, heated prior to drying $\left(\mathrm{WPI}_{\mathrm{H}} ; \diamond\right)$ and heated with calcium prior to drying $\left(\mathrm{WPI}_{\mathrm{HCa}} ; \triangle\right)$, with every 50 th profile shown.

\section{Conclusions}

The influence of nanoparticulation of whey proteins in solution, using heat- and mineral-induced controlled denaturation and aggregation, on physical and rehydration properties of the resultant WPI powders were assessed. XPS, AFM and ESEM analysis of powder surfaces showed that nanoparticulation resulted in WPI powders with more wrinkled powder particle structures, reduced wettability, greater inhibition of powder swelling, and higher levels of insoluble aggregates than the respective control WPI powder. The poor wetting properties of nanoparticulated WPI powders was likely due to higher proportions of protein at the powder surface, thereby reducing penetration and uptake of water. The results from the current study show that nanoparticulation of whey proteins modifies the surface properties of WPI powders, which influences the overall rehydration characteristics and mineral release, with important implications for applications of such powders, potentially including as nanospacers to modulate protein-protein interactions in casein-dominant powders, with associated rehydration and techno-functional benefits.

Supplementary Materials: The following are available online at https:/ /www.mdpi.com/article/10 .3390 / dairy2040047/s1, Table S1: Change in backscattered light per minute ( $\Delta B S)$ of whey protein isolate (WPI) in deionized water at $25^{\circ} \mathrm{C}$ measured after $1 \mathrm{~h}$ across the vertical axis of $40 \mathrm{~mm}$ cell. The samples are: fully dispersed WPI solution $\left(\mathrm{WPI}_{\mathrm{D}}\right)$, original control $\left(\mathrm{WPI}_{\mathrm{C}}\right)$ powder, $\mathrm{WPI}$ powder prepared without heat treatment $\left(\mathrm{WPI}_{\mathrm{UH}}\right)$, nanoparticulated powders prepared by heating $\left(\mathrm{WPI}_{\mathrm{H}}\right)$ or heated with calcium $\left(\mathrm{WPI}_{\mathrm{HCa}}\right)$ prior to drying.

Author Contributions: Conceptualisation, J.R.G., S.V.C. and J.A.O.; Methodology: J.R.G. and V.L.C.; Investigation, J.R.G., V.L.C. and V.S.N.M.; Formal Analysis: J.R.G.; Writing-original draft: J.R.G.; Writing-review and editing: R.R.P., V.S.N.M., V.L.C., B.M.G.O., S.V.C. and J.A.O.; Funding Acquisition and supervision: B.M.G.O., S.V.C. and J.A.O. All authors have read and agreed to the published version of the manuscript.

Funding: This work was funded by both the Irish Department of Agriculture, Food and the Marine and the Department of Agriculture, Environment and Rural Affairs in Northern Ireland supported by the Food Institutional Research Measure (FIRM) project "Developing the next generation of high protein spray-dried dairy powders with enhanced hydration properties" (DAIRYDRY 15-F-679).

Data Availability Statement: Data are not shared, available upon request.

Acknowledgments: The authors would like to acknowledge and thank Sean Hogan from Teagasc Food Research Centre, Moorepark for sample preparation and AFM facilities.

Conflicts of Interest: The authors declare no conflict of interest. The funders had no role in the design of the study; in the collection, analyses, or interpretation of data; in the writing of the manuscript, or in the decision to publish the results.

\section{References}

1. Kilara, A.; Vaghela, M.N. Whey proteins. In Proteins in Food Processing, 2nd ed.; Rickey, Y.Y., Ed.; Elsevier Inc.: Amsterdam, The Netherlands, 2018; pp. 93-126.

2. Chung, C.; Degner, B.; McClements, D.J. Development of Reduced-calorie foods: Microparticulated whey proteins as fat mimetics in semi-solid food emulsions. Food Res. Int. 2014, 56, 136-145. [CrossRef]

3. Esfanjani, A.F.; Jafari, S.M.; Assadpoor, E.; Mohammadi, A. Nano-encapsulation of saffron extract through double-layered multiple emulsions of pectin and whey protein concentrate. J. Food Eng. 2015, 165, 149-155. [CrossRef]

4. Lagrange, V.; Whitsett, D.; Burris, C. Global Market for Dairy Proteins. J. Food Sci. 2015, 80, A16-A22. [CrossRef]

5. Bogue, J.; Collins, O.; Troy, A.J. Market analysis and concept development of functional foods. In Developing New Functional Food and Nutraceutical Products, 1st ed.; Elsevier Inc.: Amsterdam, The Netherlands, 2017; pp. $29-45$.

6. Ji, J.; Fitzpatrick, J.; Cronin, K.; Crean, A.; Miao, S. Assessment of measurement characteristics for rehydration of milk protein based powders. Food Hydrocoll. 2016, 54, 151-161. [CrossRef]

7. Gaiani, C.; Morand, M.; Sanchez, C.; Tehrany, E.A.; Jacquot, M.; Schuck, P.; Jeantet, R.; Scher, J. How surface composition of high milk proteins powders is influenced by spray-drying temperature. Colloids Surf. B Biointerfaces 2010, 75, 377-384. [CrossRef] 
8. Barone, G.; O’Regan, J.; O’Mahony, J.A. Influence of composition and microstructure on bulk handling and rehydration properties of whey protein concentrate powder ingredients enriched in $\alpha$-lactalbumin. J. Food Eng. 2019, 255, 41-49. [CrossRef]

9. Gulzar, M.; Bouhallab, S.; Jeantet, R.; Schuck, P.; Croguennec, T. Influence of $\mathrm{pH}$ on the dry heat-induced denaturation/aggregation of whey proteins. Food Chem. 2011, 129, 110-116. [CrossRef]

10. Burgain, J.; El Zein, R.; Scher, J.; Petit, J.; Norwood, E.-A.; Francius, G.; Gaiani, C. Local modifications of whey protein isolate powder surface during high temperature storage. J. Food Eng. 2016, 178, 39-46. [CrossRef]

11. Chantrapornchai, W.; McClements, D.J. Influence of $\mathrm{NaCl}$ on optical properties, large-strain rheology and water holding capacity of heat-induced whey protein isolate gels. Food Hydrocoll. 2002, 16, 467-476. [CrossRef]

12. Joyce, A.M.; Kelly, A.L.; O’Mahony, J.A. Controlling denaturation and aggregation of whey proteins during thermal processing by modifying temperature and calcium concentration. Int. J. Dairy Technol. 2018, 71, 446-453. [CrossRef]

13. Dissanayake, M.; Vasiljevic, T. Functional properties of whey proteins affected by heat treatment and hydrodynamic high-pressure shearing. J. Dairy Sci. 2009, 92, 1387-1397. [CrossRef]

14. Dissanayake, M.; Liyanaarachchi, W.; Vasiljevic, T. Functional properties of whey proteins microparticulated at low pH. J. Dairy Sci. 2012, 95, 1667-1679. [CrossRef]

15. Krešic, G.; Lelas, V.; Herceg, Z.; Režek, A. Effects of high pressure on functionality of whey protein concentrate and whey protein isolate. Le Lait 2006, 86, 303-315. [CrossRef]

16. Ks, S.; Bimlesh, M.; Rajan, S.; Rajesh, K. Preparation and functional characterization of whey protein-maltodextrin conjugates. Res. Rev. J. Food Dairy Technol. 2017, 5, 7-16.

17. Ooi, J.Y. Whey Protein Denaturation and Aggregation during High Temperature-Short Time Thermal Processing as Influenced by Temperature and Ionic Strength. Master's Thesis, University College Cork, Cork, UK, 2015.

18. Joyce, A.M.; Brodkorb, A.; Kelly, A.; O'Mahony, J.A. Separation of the effects of denaturation and aggregation on whey-casein protein interactions during the manufacture of a model infant formula. Dairy Sci. Technol. 2017, 96, 787-806. [CrossRef]

19. Gaiani, C.; Scher, J.; Schuck, P.; Desobry, S.; Banon, S. Use of a turbidity sensor to determine dairy powder rehydration properties. Powder Technol. 2009, 190, 2-5. [CrossRef]

20. Cenini, V.; Gallagher, L.; McKerr, G.; McCarthy, N.; McSweeney, D.; Auty, M.; O’Hagan, B. A novel approach for dynamic in-situ surface characterisation of milk protein concentrate hydration and reconstitution using an environmental scanning electron microscope. Food Hydrocoll. 2020, 108, 105881. [CrossRef]

21. Vos, B.; Crowley, S.V.; O'Sullivan, J.; Evans-Hurson, R.; McSweeney, S.; Krüse, J.; Ahmed, M.R.; Fitzpatrick, D.; O’Mahony, J.A. New insights into the mechanism of rehydration of milk protein concentrate powders determined by Broadband Acoustic Resonance Dissolution Spectroscopy (BARDS). Food Hydrocoll. 2016, 61, 933-945. [CrossRef]

22. Wu, S.; Fitzpatrick, J.; Cronin, K.; Ahmed, M.R.; Fitzpatrick, D.; Miao, S. Application of broadband acoustic resonance dissolution spectroscopy (BARDS) to the gas release behaviour during rehydration of milk protein isolate agglomerates. J. Food Eng. 2019, 253, 14-20. [CrossRef]

23. Guralnick, J.R.; Panthi, R.R.; Bot, F.; Cenini, V.L.; O’Hagan, B.M.; Crowley, S.V.; O'Mahony, J.A. Pilot-scale production and physicochemical characterisation of spray-dried nanoparticulated whey protein powders. Int. J. Dairy Technol. 2021, 74, 581-591. [CrossRef]

24. IDF. International IDF Standard 20A. In Milk and Milk Products—Determination of Nitrogen Content_Part 1: Kjeldahl Principle and Crude Protein Calculation; International Dairy Federation: Brussels, Belgium, 2014.

25. IDF. International IDF standard 20A. In Dried Milk—Determination of Moisture Content; International Dairy Federation: Brussels, Belgium, 2004.

26. McCarthy, N.A.; Gee, V.L.; Hickey, D.K.; Kelly, A.; O’Mahony, S.; Fenelon, M.A. Effect of protein content on the physical stability and microstructure of a model infant formula. Int. Dairy J. 2013, 29, 53-59. [CrossRef]

27. Hutter, J.L.; Bechhoefer, J. Calibration of atomic-force microscope tips. Rev. Sci. Instruments 1993, 64, 1868-1873. [CrossRef]

28. Fitzpatrick, J.J.; Salmon, J.; Ji, J.; Miao, S. Characterisation of the Wetting Behaviour of Poor Wetting Food Powders and the Influence of Temperature and Film Formation. KONA Powder Part. J. 2017, 34, 282-289. [CrossRef]

29. GEA. A 5 b-Wettability. In GEA Process Engineering A/S; GEA: Gladsaxevej, Denmark, 2006.

30. GEA. A 3 a-Insolubility index. In GEA Process Engineering A/S; GEA: Gladsaxevej, Denmark, 2006.

31. Sun, Y.; Deac, A.; Zhang, G.G.Z. Assessing Physical Stability of Colloidal Dispersions Using a Turbiscan Optical Analyzer. Mol. Pharm. 2019, 16, 877-885. [CrossRef]

32. Crowley, S.; Desautel, B.; Gazi, I.; Kelly, A.; Huppertz, T.; O'Mahony, J.A. Rehydration characteristics of milk protein concentrate powders. J. Food Eng. 2015, 149, 105-113. [CrossRef]

33. Nikolova, Y.; Petit, J.; Sanders, C.; Gianfrancesco, A.; Scher, J.; Gaiani, C. Toward a better determination of dairy powders surface composition through XPS matrices development. Colloids Surf. B Biointerfaces 2015, 125, 12-20. [CrossRef] [PubMed]

34. Hussain, R.; Gaiani, C.; Jeandel, C.; Ghanbaja, J.; Scher, J. Combined effect of heat treatment and ionic strength on the functionality of whey proteins. J. Dairy Sci. 2012, 95, 6260-6273. [CrossRef]

35. Codina-Torrella, I.; Guamis, B.; Ferragut, V.; Trujillo, A. Potential application of ultra-high pressure homogenization in the physico-chemical stabilization of tiger nuts' milk beverage. Innov. Food Sci. Emerg. Technol. 2017, 40, 42-51. [CrossRef] 
36. Matsumiya, K.; Inoue, T.; Niida, J.; Katagiri, T.; Nishizu, T.; Matsumura, Y. Evaluation of long-term stability of milk beverages by a novel method for rapid determination of aggregation forces between colloidal particles. Food Hydrocoll. 2014, 34, 177-183. [CrossRef]

37. Jambrak, A.R.; Mason, T.J.; Lelas, V.; Herceg, Z.; Herceg, I.L. Effect of ultrasound treatment on solubility and foaming properties of whey protein suspensions. J. Food Eng. 2008, 86, 281-287. [CrossRef] 